\title{
THE EFFECTS OF A NEW PARK AND RIDE FACILITY SUPPLY IN THE CITY OF VIENNA, AUSTRIA
}

\author{
ROMAN KLEMENTSCHITZ \& PHILIPP GRASS \\ Institute for Transport Studies, University Bodenkultur, Austria
}

\begin{abstract}
Based on a field survey and 200 face-to-face interviews, the occupancy rate, the demand effects and the mobility characteristics of users (e.g. travel purpose, catchment area, travel time) of a new park and ride facility with a capacity of 234 spaces, located at a metro station in the 10th district of Vienna, were analysed. The facility opened in 2017 in the course of the extension of metro line U1 of the Viennese underground network. In parallel parking management (pay and display parking with a total maximum of 3 hours of parking time) was introduced in the built-up areas of the 10th district. Carrying out a manual counting at the park and ride facility on working days, the average occupation rate is $78.7 \%$. Some results from the interviews are as follows: the median distance between the homes of the people being interviewed and the park and ride facility is $15.0 \mathrm{~km}$, and its catchment area spreads out homogenously over the neighbouring municipalities in the region. Additionally, more than $51 \%$ claimed they were influenced by the implementation of the Viennese pay and display system in the 10th district of Vienna. More than $50 \%$ have good knowledge of their alternative of using public transport for the whole journey instead of using the park and ride facility. Nevertheless, only $25 \%$ of the interviewees stated that they use public transport at their place of residence in the surrounding regions of Vienna on a regular basis. There is no significant difference between men and women with regard to the perception of security while using the park and ride facility. The majority of respondents hold a transit pass, mostly as an annual pass, to use the urban public transport. The paper and presentation will give more detailed information of the results of the research work.

Keywords: park and ride, intermodality, urban transport, transport behaviour.
\end{abstract}

\section{INTRODUCTION}

Parking management, especially the provision of park and ride facilities, plays an important role in the transport system of conurbation areas. Interviews with policy makers across Europe underline the high expectations towards the positive effects of park and ride measures on the one hand, both in environmental and economic terms [1]. On the other hand, Piccione et al. criticises the lack of common understanding in selecting specific parking measures in conurbation areas as links between such parking systems and contexts within which they work are generally not investigated [2]. Park and ride facilities combine two transport modes and the mode change takes place at the area, where both attractive public transport supply and capacity problems increase, usually the edge of the city or corridors into the city. The effects of park and ride facilities with regard to sustainable mobility are discussed in many European cities, especially if located close to the edge of the cities. Some analysis showed a positive impact on the balance in car mileage, as the commuters are attracted to drive to the facility instead of using public transport in the region [3]. In a meta-analysis of 40 different studies including 180 facilities [4], the results were ambivalent. park and ride facilities at the edge of the cities reduce the number of car trips into the cities, but the balance on public transport mileage is insignificant (decreasing mileage in the catchment area and increasing mileage within the city). These findings, together with the implementation of a new park and ride facility in Vienna, were the motivations to analyse this site and its contribution to sustainable mobility. 
Vienna has a dense railway and metro network and the transport policy is focusing on providing park and ride facilities at rail-based services in the region and the edge of the city [5]. Whereas park and ride facilities in the (rural) regions are free of use, there exists a pricing scheme for park and ride facilities at the edge of and within the city. In parallel, parking pricing and short-term parking is implemented in the densely populated area of the city territory. The park and ride facility Wien-Oberlaa is located at the southern edge of the city was opened in parallel with the extension of the metro line U1 in autumn 2017. Additionally, the parking pricing and short-term parking zone was extended at the same time, covering the whole area including the area surrounding the metro station. The capacity of the facility is 234 spaces and the ticket for parking is $€ 3.40$ for entering the facility, which includes a parking permission until the end of the day of entrance. The headway of the metro at working days is $4 \mathrm{~min}$ in peak time and $7 \mathrm{~min}$ in off peak time during the day and $15 \mathrm{~min}$ late evening after 21:00 hours. First train departs 4:57 hours in the morning, last train arrives $0: 44$ hours beyond midnight. In the focus of this research work are the behaviour of the users, their origin and destinations, purpose and distance of their trip, frequency of usage and duration of stay. Additionally the respondents were asked about their knowledge with regard to alternatives (i.e. using public transport for the whole trip instead of), the influence of the changed framework conditions (i.e. the new metro and park and ride supply, the extended parking pricing area) and the perception with regard to security at the site. In parallel the load factor was surveyed at the facility.

\section{METHODOLOGY}

The users of the park and ride facility were asked face to face at site. All answers were filled in a paper form, partly predefined answer categories, partly to rank a scale and partly as open answer option. The survey included 20 questions, which allowed using a one double sided A4 form (Fig. 1). For the interview a place was selected, where the users are passing by, if arriving with the car or metro and heading for the next transport mode. As this area is owned by the operator of the park and ride facility, a permit was obtained prior to the interviews. The survey was executed in June 2018, covering all working days and day times. In total 200 persons were interviewed, and the response rate was above $80 \%$. There was a clear procedure defined, how to select the respondents depending on the frequency of users passing the interviewer. In times of low demand all persons were interviewed, in times of high demand (and in case a metro was arriving) the tenth person passing was selected for the interview after having completed an interview. For surveying the load factor, the parked cars were counted at 20 working days in summer 2018.

\section{LOAD FACTOR OF FACILITY}

On average the load factor of the park and ride facility is nearly $80 \%$ at midday, when the highest occupation rate is expected. The peak was $88 \%$ and the lowest occupation with $66 \%$. These values are in line with surveys from 2013 [6], if compared with park and ride facilities in areas with combined parking pricing and short-term parking. There is a clear relationship in the result of this study from 2013, if no pricing exists in the area of the facility a lower load factor can be expected at the park and ride facility. Similar results have been observed in a before and after study for a case study in Athens [7], where the load factor of a park and ride facility increased significantly after the introduction of an on-street parking pricing scheme. There are no clear differences between specific days of the week to be recognised in the surveyed data, whereas a smooth decline over time can be seen as holiday season is starting in Austria by July (Fig. 2). The current load factor is in line with the expectations of 
the operator of the facility, an extension is planned. A construction of a multi storey car park is envisaged at this site in the future.

\begin{tabular}{|c|c|c|}
\hline & & ANMERKUNGEN: \\
\hline \multirow{3}{*}{$\begin{array}{c}\text { 1. Mit welchem Fahrzeug sind Sie heute zur } \\
\text { P+R-Anlage gekommen? } \\
\text { Einspurige KFZ sind ausgeschlossen }\end{array}$} & PKW als Lenker/in & \\
\hline & PKW als Mitfahrer/in & \\
\hline & Sonstiges: & \\
\hline \multirow{5}{*}{$\begin{array}{l}\text { 2. Bitte geben Sie Ihre Quelle bzw. Ihr Ziel so } \\
\text { genau wie möglich an. } \\
\text { In Wien: Zumindest Straße; } \\
\text { Außerhalb Wiens zuminndest Gemeinde bzw. } \\
\text { Ortschaft }\end{array}$} & Quelle: & \\
\hline & Ziel: & \\
\hline & Quelle ist Wohnort & \\
\hline & Ziel ist Wohnort & \\
\hline & \multicolumn{2}{|l|}{ Wohnort (falls nicht Quelle oder Ziel): } \\
\hline \multicolumn{3}{|l|}{$\begin{array}{l}\text { 3. Was ist der Wegzweck ? } \\
\text { Arbeit }>\text { Bildung>Einkauf }>\text { Freizeit }\end{array}$} \\
\hline $\begin{array}{l}\text { 4. Kennen Sie die ungefëhre Distanz } \\
\text { zwischen Quelle und Ziel? }\end{array}$ & \multicolumn{2}{|l|}{$\mathrm{km}$} \\
\hline $\begin{array}{l}\text { 5. Wie lange brauchen Sie für die gesamte } \\
\text { Strecke durchschnittlich? } \\
\text { Gefragt ist die Fahrzeit }\end{array}$ & \multicolumn{2}{|l|}{$\min$} \\
\hline \multirow{3}{*}{$\begin{array}{l}\text { 6. Welche P+R-Anlage ist threm Wohnort am } \\
\text { nächsten? }\end{array}$} & Diese & \\
\hline & Folgende: & \\
\hline & Weiß nicht & \\
\hline \multirow{4}{*}{$\begin{array}{l}\text { 7. Wie oft sind Sie in der letzten Woche zur } \\
\text { P+R-Anlage Oberlaa zugefathren? } \\
\text { Z.B. Morgens zufahrren, PRW abstellen, } \\
\text { abends wegfahren = } 1 \text { Zufahrt/Tag }\end{array}$} & Mehr als 4 Mal & \\
\hline & 2-4 Mal & \\
\hline & $1 \mathrm{Mal}$ & \\
\hline & Gar nicht & \\
\hline $\begin{array}{l}\text { 8. Wie lange haben Sie Ihr Fahrzeug heute an } \\
\text { der P+R-Anlage abgestellt bzw. werden Sie } \\
\text { es abstellen? }\end{array}$ & \multicolumn{2}{|l|}{$\mathrm{h}$} \\
\hline \multirow{4}{*}{$\begin{array}{l}\text { 9. Welches Ticket nutzen Sie für die P+R- } \\
\text { Anlage Oberlaa? }\end{array}$} & Tageskarte & \\
\hline & Wochenkarte & \\
\hline & Monatskarte & \\
\hline & Jahreskarte & \\
\hline \multirow{3}{*}{$\begin{array}{l}\text { 10. Welches Verkehrsmittel haben Sie nach } \\
\text { Abstellen lhres Fahrzeuges benutzt? }\end{array}$} & U-Bahn (U1) & \multirow[t]{3}{*}{ Sonstige: } \\
\hline & Stadtbus $(17 \mathrm{~A}, 68 \mathrm{~B}, 70 \mathrm{~A})$ & \\
\hline & Regionalbus $(226,227,266)$ & \\
\hline \multirow{5}{*}{$\begin{array}{l}\text { 11. Wie sicher fühlen Sie sich auf dem } \\
\text { Gelände der P+R-Anlage auf einer Skala von } \\
1 \text { (sehr sicher) bis } 5 \text { (nicht sicher) nach } \\
\text { Schulnoten? }\end{array}$} & [1] Sehr sicher & \\
\hline & [2] Sicher & \\
\hline & [3] Neutral & \\
\hline & [4] Wenig sicher & \\
\hline & [5] Nicht sicher & \\
\hline
\end{tabular}

\begin{tabular}{|c|c|c|}
\hline $\begin{array}{l}\text { 12. Gibt es für Sie, abgesehen von dieser } \\
\text { P+R-Anlage, iene andere Möglichkeit, um Ihr } \\
\text { heutiges Ziel zu erreichen? } \\
\text { Bitte beschreiben Sie. }\end{array}$ & & $\begin{array}{l}\text { Andere P+R-Anlage, } \\
\text { anderes KFZ...usw. }\end{array}$ \\
\hline \multirow{3}{*}{$\begin{array}{l}\text { 13. Könnten Sie diesen (heutigen) Weg auch } \\
\text { ausschließlich mit dem öffentichen Verkehr } \\
\text { bewältigen? } \\
\text { Wöre eigenes KFZ entbehrlich, reiner Weg mit } \\
\text { ÖVmöglich? }\end{array}$} & Ja: Bitte beschreiben Sie! & \multirow[t]{3}{*}{ 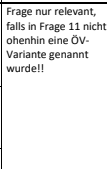 } \\
\hline & \begin{tabular}{|l} 
Nein: Warum nicht? \\
\end{tabular} & \\
\hline & Weiß nicht & \\
\hline \multirow{4}{*}{$\begin{array}{l}\text { 14. Wie haben Sie diesen Weg vor Eröffnung } \\
\text { der P+R-Anlage Obelaaa und der U1 } \\
\text { zurückgelegt? } \\
\text { Setzt voraus, dass bestimmtes Ziel seit } \\
\text { längerem existiert nnd der Weg dorthin auch } \\
\text { schon vor dem 02.09.2017 durchgeführt } \\
\text { wurde. }\end{array}$} & Andere P+R-Anlage benutzt & \multirow[t]{4}{*}{ Sonstiges: } \\
\hline & $\begin{array}{l}\text { Ausschließlich mit eigenem KFZ } \\
\text { gefahren }\end{array}$ & \\
\hline & $\begin{array}{l}\text { Ausschließlich mit dem } \\
\text { offentlichen Verkehr gefahren }\end{array}$ & \\
\hline & $\begin{array}{l}\text { Zu dieser Zeit (noch) kein } \\
\text { vergleichbarer Weg }\end{array}$ & \\
\hline \multirow{4}{*}{$\begin{array}{l}\text { 15. Hat die Einführung des Parkpickerls in } \\
\text { Wien-Favoriten einen Einfluss auf die Wahl } \\
\text { IIres Weges bbw. des Verkehrsmittels? } \\
\text { Parkraumbewirtschaftung gilt seit 04.09.17 }\end{array}$} & Auf die Wahl des Weges/der Route & \\
\hline & Auf die Wahl des Verkehrsmittels & \\
\hline & Auf beides & \\
\hline & Weiß nicht & \\
\hline \multirow{4}{*}{$\begin{array}{l}\text { 16. An wie vielen Tagen pro Woche nutzen } \\
\text { Sie den öffentlichen Verkehr in Ihrer } \\
\text { Heimatgemeinde? } \\
\text { Pro Tag beliebig viele Fahrten möglich }\end{array}$} & Mehr als 4 Tage pro Woche & \\
\hline & 2-4 Tage pro Woche & \\
\hline & 1 Tag pro Woche & \\
\hline & Gar nicht & \\
\hline \multirow{6}{*}{$\begin{array}{l}\text { 17. Bitte geben Sie an, welche Zeitkarte für } \\
\text { den öffentlichen Verkehr Sie nutzen? } \\
\text { Jahres- und Monatskarten gibt es sowohl vom } \\
\text { Verkehrsverbund Ostregion (VOR) als auch } \\
\text { den Wiener Linien (diese gelten aber nur für } \\
\text { Wien) }\end{array}$} & \begin{tabular}{|l} 
Jahreskarte (VOR) \\
\end{tabular} & \\
\hline & Jahreskarte (Wiener Linien) & \\
\hline & Monatskarte (VOR) & \\
\hline & Monatskarte (Wiener Linien) & \\
\hline & Sonstige: & \\
\hline & Keine & \\
\hline \multirow{2}{*}{$\begin{array}{l}\text { 18. Wussten Sie, dass Sie durch den Besitz } \\
\text { einer Zeitkarte für den offentlichen Verkehr } \\
\text { Vergünstigungen bee der Benüttung der } P+R \text { - } \\
\text { Anlage erhalten? }\end{array}$} & Ja & \\
\hline & Nein & \\
\hline \multicolumn{3}{|l|}{ 19. Geburtsjahr } \\
\hline 20. Geschlecht & w口 & \\
\hline
\end{tabular}

Figure 1: The layout of the questionnaire for the face-to-face interviews (front and back side).

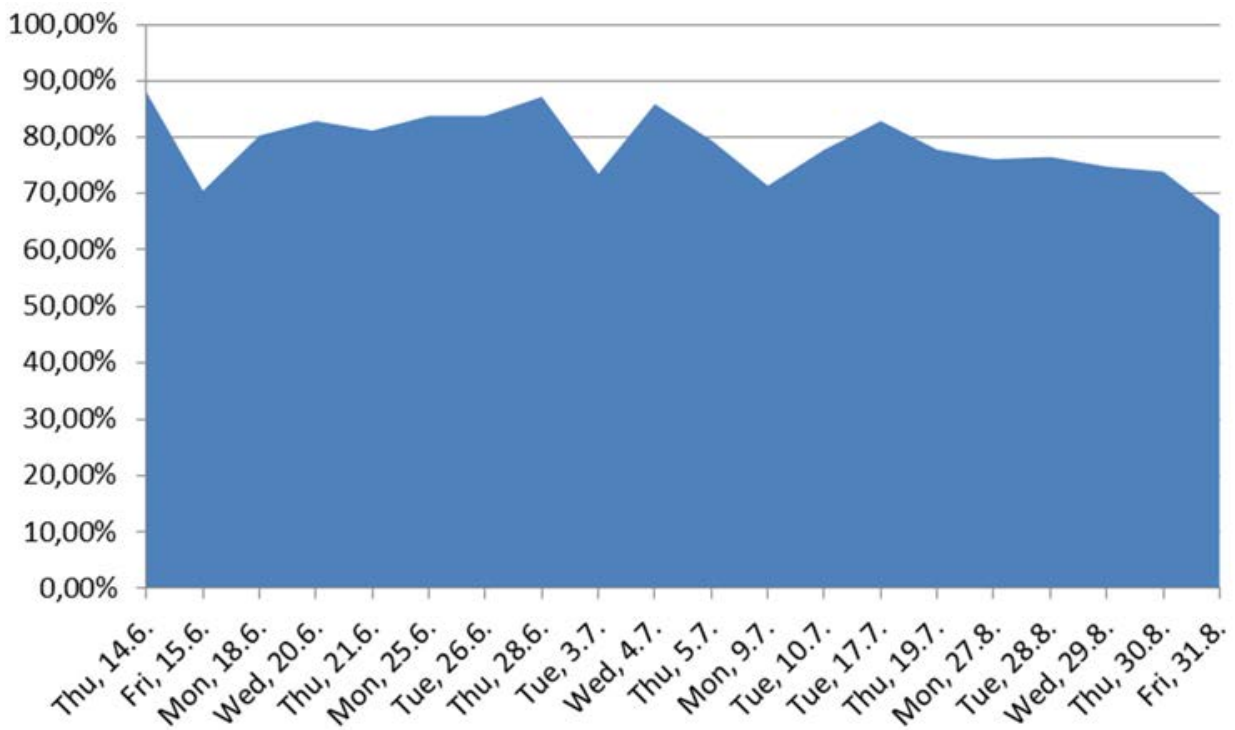

Figure 2: Load factor of park and ride facility Oberlaa, Vienna, working days in summer time 2018. 


\section{TRANSPORT BEHAVIOUR OF PARK AND RIDE USERS}

The following chapter is based on the analyses of the statements of the respondents of the face-to-face interviews, which took place on workdays in June 2018, 200 persons were interviewed.

\subsection{Socio-demographic data of users}

Looking at the gender, with $59.5 \%$ a majority of female users can be observed among the park and ride facility users, the average age is 44.2 years. The youngest respondent was 15 (arriving by a motorcycle), the oldest person was aged 83 . There is a relative even distribution of age within these two extreme points. However, classified by trip purpose, as expected, there are differences in the age, with education 23.9 years, working 42.3 years, leisure/recreation 47.6 years and shopping/errand 56.2 years on average.

\subsection{Mode shares, parking duration and trip purpose}

As expected, the vast majority is arriving (or leaving) with the car as driver $(94.0 \%)$. However, another $5.0 \%$ are car passenger and $1.0 \%$ users of motorcycles (which are not charged for parking at the park and ride facility). On the other side, the majority of the public transport type used (arriving or leaving) was the metro line with $90.5 \%$, only $0.5 \%$ used a local bus line. An interesting fact, that $6.0 \%$ reached their target by walking and other $3.0 \%$ used the car park as meeting point for ride sharing, which both is no intended type of usage of the facility on the one hand. However, it is not prohibited on the other hand. On average the vehicle was parked 7.7 hours, the distribution of the parking time can be seen on Fig. 3. The majority are parking less than 12 hours, within this group the individual duration of parking is evenly distributed whereas a small user group park their car 24 hours. Looking at the trip purpose (Fig. 4), working is the dominating aspect, followed by leisure trips. Parking time relates to the trip purpose as those going to work or to educate themselves park their vehicle longer in comparison to leisure, shopping or errands.

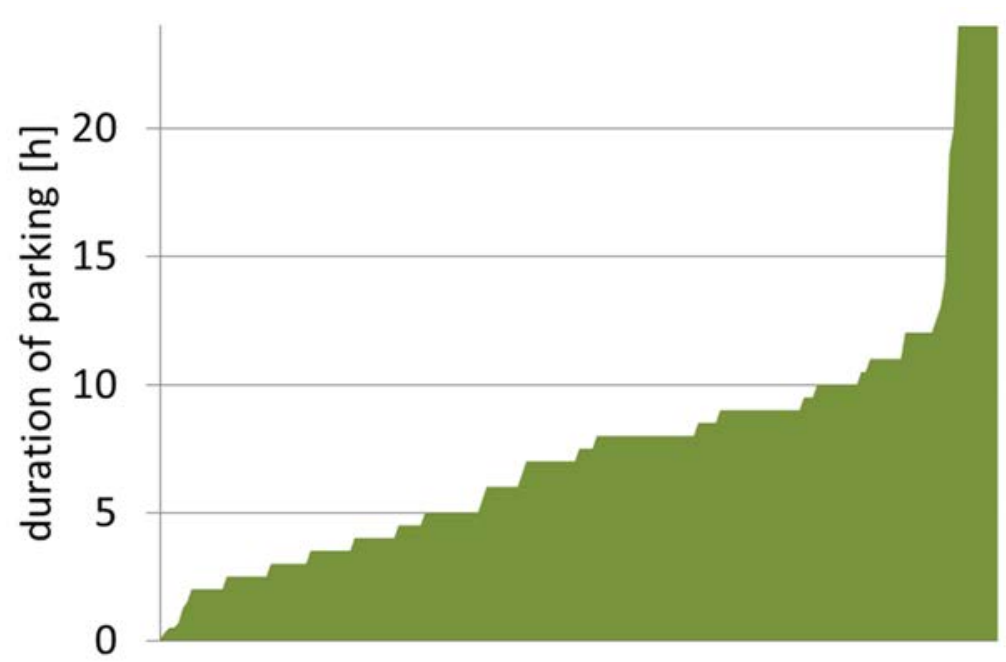

Figure 3: Distribution of the parking time at park and ride facility (workday, June 2018, $n=200$ respondents). 


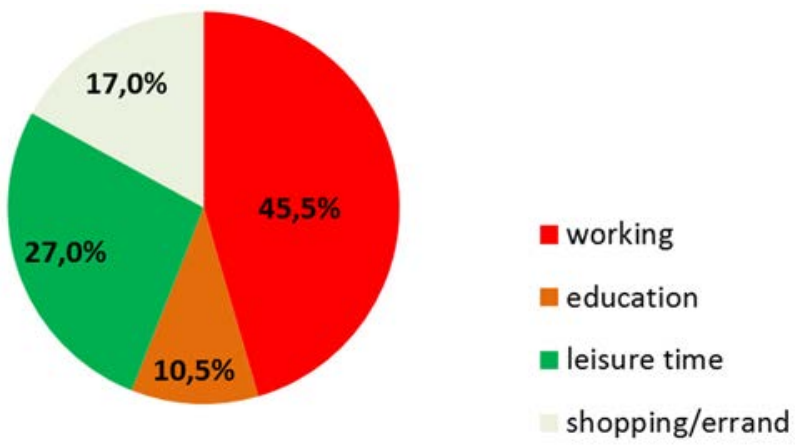

Figure 4: The distribution of trip purpose for park and ride trips (workday, June 2018, $n=200$ respondents).

\subsection{Catchment area, trip length and frequency of usage}

Respondents were asked about their origin and destinations of their trip. For all of them, at least their destination or origin was within the city. With $90 \%$, for the big majority, the opposite point of the trip was outside of the city. The other 10\% started (mostly) in the vicinity of the park and ride facility within the city to park their car and continue with means of public transport. Fig. 5 gives an overview of the spatial distribution of the starting points or destinations (all locations are displayed mentioned more than one time).

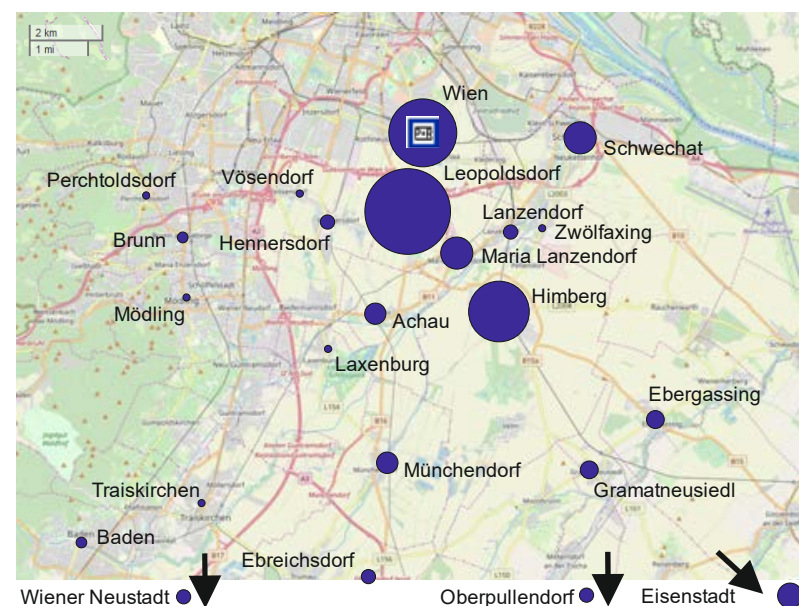

Figure 5: The spatial distribution of starting and destination points of park and ride trip mentioned more than one time, size of cycle represents 2 times as the smallest up to 24 times as the biggest (Leopoldsdorf), workday, June 2018, $n=200$ respondents.

The size of the cycle represents the number of origins and destinations of the municipality. The location of the park and ride facility is additionally displayed. A clear southeast orientation can be seen in the catchment area of the park and ride facility and a concentration 
of users from neighbouring municipalities such as Leopoldsdorf and Himberg. This reflect the public transport supply in the region, especially in the west of the park and ride facility the next metro line with its own park and ride facility satisfy the commuters of this area. However, the average distance travelled to the park and ride facility arriving/departing with private motorised means of transport is $29.34 \mathrm{~km}$ (which includes some outliers arriving from Germany and the West of Austria), the $50 \%$ median is $15 \mathrm{~km}$.

Fig. 6 gives an overview of the distribution of travel time for the whole trip between the origin and the destination of the trip. The $50 \%$ median of the travel time including all modes used is 56.5 minutes. Fig. 7 shows the distance classes for the whole trip. The largest group travels between 10 and $20 \mathrm{~km}$, nearly two third less than $20 \mathrm{~km}$, which corresponds to a travel time less than an hour.

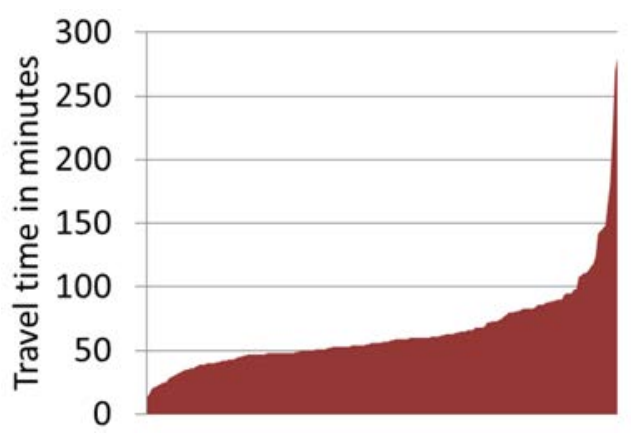

Figure 6: Distribution of travel time for the whole park and ride trip workday, June 2018, $n=200$ respondents.

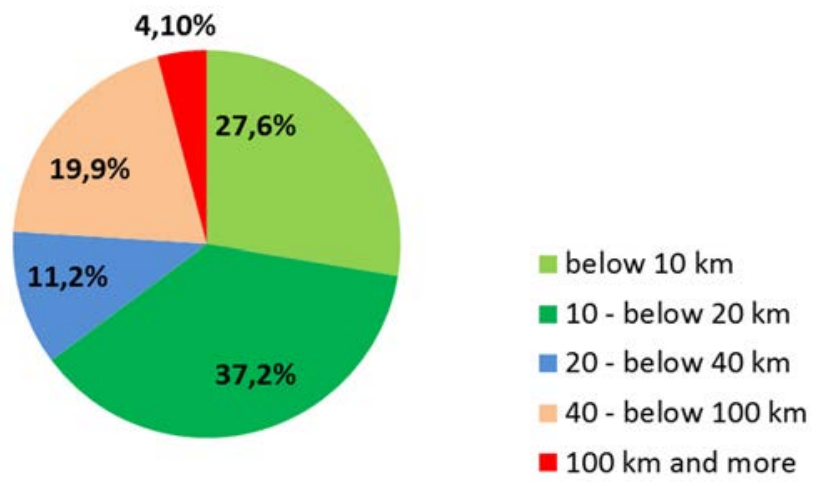

Figure 7: Distribution of travel distance for the whole park and ride trip workday, June 2018, $n=200$ respondents.

Fig. 8 shows the frequency of days, and how often the park and ride facility is used by the respondents during the week. It is less than expected, at only $17.5 \%$ are daily users, at least with regard to the working days (i.e. 5 times or more). The majority are infrequent users not more than one time per week. However, $58.1 \%$ of the users of the park and ride facility possess a time-based public transport ticket at least for a whole weak, 38.9\% a season ticket 
for the whole year. For $58 \%$ of the users of the park and ride facility, it is the nearest park and ride facility from their place of residence. $11 \%$ stated that the nearest park and ride facility is the station of Siebenhirten next to metro line U6, which is not used because of individual route optimisation. $14.5 \%$ stated the nearest park and ride facility would be at a suburban railway station close to their place of residence, which was not used because of inadequate public transport supply (mainly the frequency of trains).

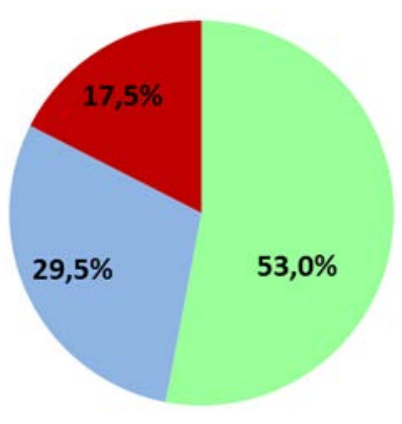

\section{up to one time per week \\ 2-4 times per week}

5 times per week and above

Figure 8: Distribution of frequency of usage of the park and ride facility, June 2018, $n=$ 200 respondents.

\section{KNOWLEDGE, PERCEPTION AND BEHAVIOURAL CHANGES}

As the extension of the park and ride supply is supported by the region as one element in meeting the goals of sustainable transport, the interviews included questions with regard to the effect of the facility on individual mobility demand. Therefore, all respondents were asked, how they made this trip before the park and ride facility was opened in combination with on street parking pricing and the metro line extension in autumn 2017. Fig. 9 shows the distribution of the answers.

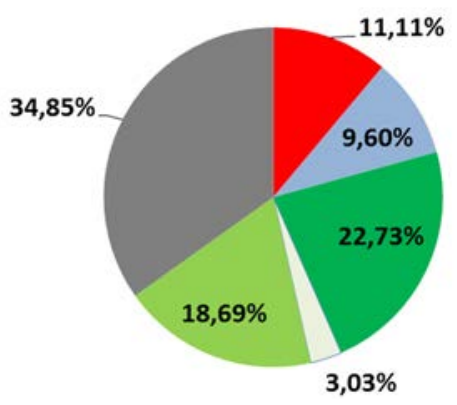

\footnotetext{
I rode the full trip using public transport

I I have used an other park and ride fcility

I l parked on street in a free parking area of the district $\square$ I parked on street in a free parking area of another district I I drove the full trip with my car

No comparable trip before
}

Figure 9: How respondents travelled before the opening of the metro line and the park and ride facility, workday, June 2018, $n=200$ respondents.

Although the time span was very small, a third of the respondents characterise the current trip as very unique and they are not able to compare it with a similar prior situation (e.g. visiting the city of Vienna the first time ever); $18.59 \%$ stated that they drove the full length with their car before. This group of respondents is in line with the intended policy, causing a 
reduction in car mileage. Another $25.76 \%$ stated that they parked their car on street changing to public transport at a different place (either in the same district or in another district), very likely closer to the city centre. Another group reduced their car mileage; $9.6 \%$ stated that they changed the location of the park and ride facility. As pricing schemes are comparable, very likely this behavioural change is caused by a reduction of the duration of the trip or the increase of the quality of the trip (e.g. a less congested route). For this group it remains unclear if this additionally causes a reduction in car mileage. $11.11 \%$ stated that they changed their behaviour by using the car for the first leg of the trip instead of riding by means of public transport the full way. This is obviously an unintended rebound effect of the new supply. A specific question was related to the influence towards the decision of modes and route choice due to the introduction of the pricing scheme in the district surrounding the new park and ride facility. $48.5 \%$ stated that there was no influence on their decision to use this park and ride facility, whereas $29.3 \%$ stated there was an influence with regard to the route and another $22.2 \%$ stated that there was an influence on mode choice (and therefore route choice).

Another aspect of interest is the knowledge about the distance and travel time of the park and ride trip, to verify, if respondents over- or underestimate their trip. Therefore, the respondents were asked about their estimation on trip length and travel time. These values were compared with a journey planner, which consider real time traffic conditions during the daytime of the trip made. The values were compared with the statements and classified in 6 classes: less than $50 \%$ underestimated, underestimation of 50-80\%, good knowledge within an deviation margin of $80-120 \%$, overestimation of $120-200 \%$, more than $200 \%$ overestimated and finally an own class, where respondents have no idea about distances and/or travel time. Additionally, a second hierarchy was introduced with three groups of respondents: (1) bad knowledge about the real values (the groups less than 50\% and above $200 \%$ and the ones with no idea; (2) weak knowledge about the real values (the groups between $50 \%$ and $80 \%$ and between $120 \%$ and $200 \%$; (3) good knowledge in a margin of $80-120 \%$ of the real value. With regard to the distance, the distribution of the knowledge level, good, weak and bad knowledge, is $37.8 \%, 27.6 \%, 34.7 \%$, which equals a very even distribution. Contrary to this, the travel time was estimated more exactly, $35.9 \%$ had good knowledge, $52.8 \%$ had weak knowledge and only $11.3 \%$ had bad knowledge about the travel time of the park and ride trip. This leads to the conclusion that people more take care about their time schedule and need to think about the time of departure and/or arrival in time rather than the trip distance, which more relates to travel costs. Time is a more important issue than travel cost obviously. If one split the classes in overestimation and underestimation of the values, with regard to the distance, it can be observed that respondents more likely underestimate the distance $(21.4 \%)$ than overestimate it $(8.2 \%) .37 .8 \%$ were within an acceptable margin and another $32.7 \%$ had no idea about the distance. Again, a totally different picture if it comes to travel time. Those, who underestimated the travel time is the majority with $58.5 \%, 34.9 \%$ had a good impression about their travel time and only $5.1 \%$ overestimated the travel time. Just $1.5 \%$ had no idea about it.

Beside the knowledge about travel time and distance, the knowledge of the alternative modes is of interest, especially whether respondents are able to give information about the public transport trip for the whole trip. Again, the statements were compared with a route planner and the results were classified in three groups: (1) good knowledge; (2) acceptable knowledge, if some mistakes were noticed by the interviewer, but within a margin, that respondents should be able to travel with means of public transport, e.g. a wrong bus number or station name, but the correct route in principle; (3) bad or no knowledge, e.g. referring on not existing public transport connections. Fig. 10 shows the results. Additionally, the respondents were grouped in frequent travellers (more than 4 times per week), regular 
travellers (2-4 times per week) and infrequent travellers including newcomers (less than 2 times per week). As expected, there is a relation between the frequency of trips and the knowledge about the public transport system. Nevertheless, the majority of the respondents in all groups own a good knowledge, how to travel by means of public transport for the whole trip. That means the decision to use the park and ride facility is based on information about the alternatives, only $3 \%$ of the frequent travellers have no knowledge about this alternative mode choice. The share of respondent with no knowledge about alternatives is similar between the other groups of travellers.

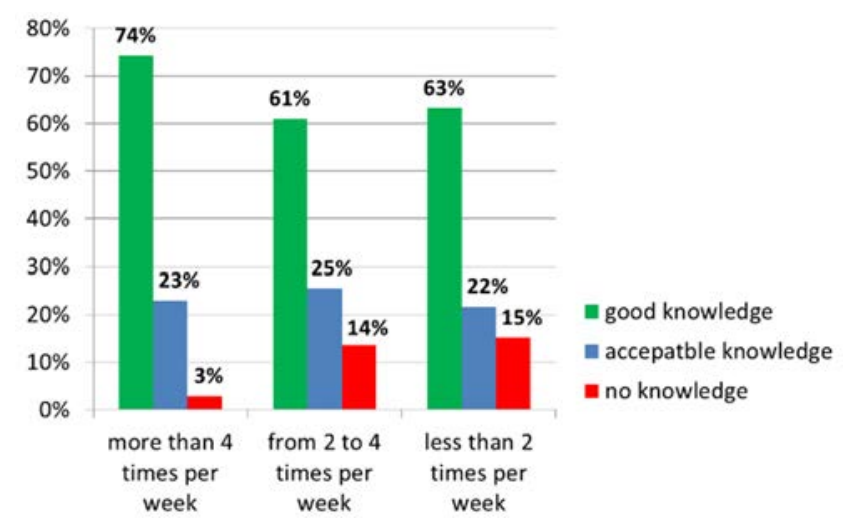

Figure 10: Knowledge of respondents, how to execute the whole trip by means of public transport instead of using the park and ride facility in dependency of trip frequency, workday, June 2018, $n=200$ respondents.

A final issue to be asked is the perception of security at the park and ride facility itself. Results are shown in Fig. 11. The big majority either feel safe or very safe, only a share of $5.5 \%$ is not satisfied. If separating male and female respondents, surprisingly females feel slightly safer than males. $4.2 \%$ of females are not satisfied, whereas $7.2 \%$ of males are not satisfied with the security situation at the site. However statistical tests do not confirm significance on that result because of the small sample size.

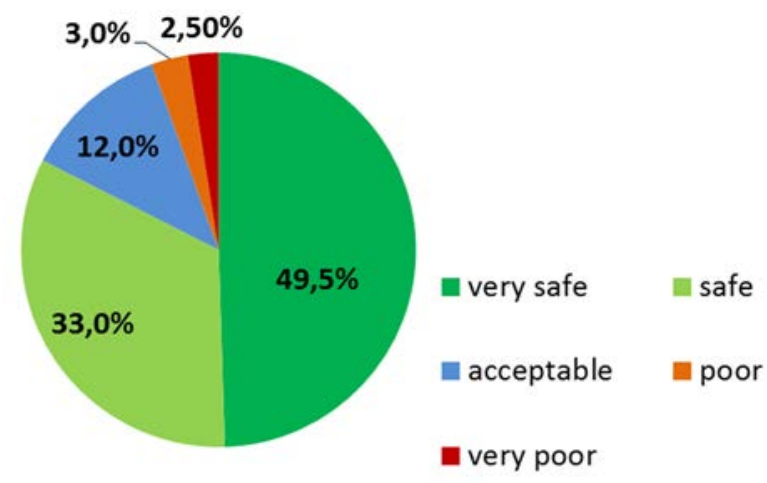

Figure 11: Subjective perception of security at the park and ride facility, workday, June $2018, n=200$ respondents. 


\section{CONCLUSIONS}

Based on the results of the study, the positive contribution of the park and ride facility towards sustainable mobility can be confirmed. Nearly every second user reduced his/her personal travel mileage because of the new park and ride supply and only a minority increased their personal travel mileage. The attractive public transport system (a metro line) and the extension of on street parking pricing in the city of Vienna are supporting this effect. A big majority of the users do know about their alternatives using the public transport for the whole trip, which means they actively decided for a park and ride trip under given information. The load factor is no restricting argument, not to use the park and ride facility so far, vacant spaces were available at any time of the survey. The catchment area of the park and ride facility is $10 \mathrm{~km}$ on average, the origins of the park and ride trips reflecting the existing public transport network and its corresponding supply. The weaker the supply, the more visitors arrive from this area. The frequency of the usage per week with more than $50 \%$ visiting not more than one time per week was surprisingly low. With a share of $45.5 \%$, working trips are the majority of park and ride trips but are not dominating the trip purpose distribution.

The findings of this study for the planning of park and ride facilities can be summarized as following: It is confirmed, park and ride facilities at the edge of cities are relieving the city centre road network. But there is always a risk, regional public transport demand decreases at the same time respectively does not utilise the potential demand. On the long term, this could have a negative impact on the regional public transport supply. A further mode shift in the region can only be stimulated by an improvement of the regional public transport system outside the city or introducing further restrictions for motorised individual travel modes such as road and parking pricing (increasing tariffs for park and ride facilities closer to the city centre). Parking restrictions in the city centres, such as the reduction of capacities or the limitation of long-term parking spaces are clearly supporting the success of park and ride facilities. Revenues of parking (and road pricing) should be used for improvements in the regional public transport supply (and park and ride facilities in the region). If the focus lies in the maximisation of public transport demand (and therefore maximise the contribution towards sustainable mobility), commuters should be motivated to use their nearest park and ride facility which could be influenced by attractive ticket packages (park and ride and public transport, with a discount if choosing park and ride facilities closer to the place of residence).

\section{REFERENCES}

[1] Dijk, M., \& Montalvo, C., Policy frames of park and ride in Europe. Journal of Transport Geography, 19, pp. 1106-1119, 2011.

[2] Piccioni, C., Valtorta, M \& Musso, A., On-street parking management: Bridging the gap between theory and practice, in Dell'Acqua, G. \& Wegman, F. (eds), Transport Infrastructure and Systems, CRC Press, Taylor \& Francis Group: London, pp. 777-785, 2017.

[3] Parkhurst, G. \& Meek, S., The effectiveness of park-and-ride as a policy measure for more sustainable mobility. Parking Issues and Policies (Transport and Sustainability, Volume 5), eds S. Ison \& C. Mulley, Emerald Group Publishing, pp. 185-211, 2014.

[4] Zijlstra, T., Vanoutrive, T. \& Verhetsel, A., A meta-analysis of the effectiveness of park-and-ride facilities. European Journal of Transport and Infrastructure Research, 15, 597-612, 2015.

[5] Department for Urban Development Vienna, Municipal Department 18 - Urban Development and Town Planning, Fachkonzept Mobilität, Miteinander mobil (Mobility masterplan. Mobile with each other). Workshop report no. 145, 2015. 
[6] Rittler, T., Einpendler nach Wien (Commuting towards Vienna). Unpublished report, Vienna, 2013.

[7] Kepaptsoglou, K. et al., Effects of a new on-street parking management scheme on parkand-ride facility demand: A preliminary before-after analysis. Advances in Transportation Studies, B-22, pp. 75-80, 2010. 